\title{
INHIBITION OF THE CARDIOVASCULAR EFFECTS OF ACUPUNCTURE (MOXIBUSTION) BY PROPRANOLOL IN DOGS DURING HALOTHANE ANAESTHESIA ${ }^{\circ}$
}

\author{
D.C. Lee, M.O. Lee, D.H. Clifford, and L.E. Morris $†$
}

ACupuncture has been used in the Orient for over 2,000 years., ${ }^{1,2}$ Recent reports have stimulated interest in this modality of treatment, but it is not widely accepted due to lack of well-controlled clinical studies, ${ }^{3-9}$

Stimulation of acupuncture loci or acupoints can be provided in various ways including pressure, cupping, needling alone, needling with twirling, needling with electrostimulation, electrostimulation alone, and application of heat by various means such as moxat and electrocautery. Classical methods of acupuncture include: (1) needling alone, (2) needling with twirling, (3) needling with electrical stimulation, and (4) burning of moxa upon the skin (moxibustion).$^{10-17}$

Marked changes in the cardiovascular system have been observed following acupuncture in dogs under halothane anaesthesia. ${ }^{18-20}$ Moxibustion by electrocautery at Jen Chung (Go-26) produced greater changes in cardiovascular parameters than pressure alone, needling alone, needling with twirling or needling with electrical stimulation. ${ }^{18,21,22}$

There is evidence that the effects of acupuncture are mediated through the autonomic nervous system. ${ }^{3,19}$ Since stimulation of the Jen Chung (Go-26) locus produced a consistent sympathomimetic effect in dogs under halothane anaesthesia, the ensuing study was formulated to determine if administration of the $\beta$-adrenergic blocking agent propranolol would inhibit this effect. ${ }^{18,10,21,22}$

Moxibustion with electric cautery was selected as the means of stimulating Jen Chung (Go-26) since the cardiovascular response produced by moxibustion is greater than that observed following acupuncture performed by needles. ${ }^{22}$

\section{Methods AND Materials}

This study was performed in 34 random-source conditioned dogs in which an electromagnetic flow probe (Zepeda) had been implanted around the ascending aorta as previously described. ${ }^{18,19,21,23,24}$ After implantation, the dogs were observed for about ten days to ensure proper recovery and that the flow probes were well tolerated.

\footnotetext{
- Supported in part by GRS Grant \#5-S01 RR 05700-04 and the Northwestern Ohio Heart Association.

†From the Departments of Anaesthesia, Physiology and Anatomy and the Division of Laboratory Animal Medicine, Medical College of Ohio, Toledo, Ohio 43614, U.S.A.

$\$ A$ moxa is a tuft of soft, combustible material which is bumed on the skin. Originally moxibustion referred to the burning of a moxa upon the skin. In this article thermal stimulation will be provided by an electric probe.
} 
The dogs were subsequently anaesthetized with thiopentone $(15 \mathrm{mg} / \mathrm{kg})$, intubated with a cuffed tracheal tube and attached to an animal pump respirator. ${ }^{\circ}$ The intake port of the respirator was attached to an anaesthetic machine $f$ furnishing 0.75 per cent halothane (MAC I) from a Copper Kettle vaporizer in 100 per cent oxygen. Apnoea was maintained by an intravenous drip of succinylcholine $(1 \mathrm{mg} / \mathrm{ml})$ in isotonic saline. The respiratory volume was adjusted to maintain the $\mathrm{Pa}_{\mathrm{CO}_{2}}$ at $40 \pm 2$ Torr.

A three-way $\mathrm{BD}$ connector attached to a catheter in the femoral artery permitted the removal of anaerobic blood samples and measurement of systolic and diastolic pressures. Arterial samples were analyzed for $\mathrm{Pa}_{\mathrm{CO}_{2}}, \mathrm{~Pa}_{\mathrm{O}_{2}}$ and $\mathrm{pH}$ by means of a triple electrode system. . $^{25-27}$ Mean arterial pressure (MAP) was calculated as follows: MAP $(\mathrm{mm} \mathrm{Hg})=$ Diastolic pressure + (systolic pressure-Diastolic pressure) $/ 3$. The pulse pressure was determined by subtracting the diastolic pressure from the systolic pressure.

Central venous pressure was measured by means of a polyethylene catheter inserted into the femoral vein. The pressure was measured visually from a graduated plastic tube filled with isotonic saline.

Total peripheral resistance (TPR) was calculated according to Green's formula: ${ }^{28}$ Total peripheral resistance $\left(\right.$ dyne $\left./ \mathrm{sec} / \mathrm{cm}^{-5}\right)=($ MAP $\times 1332 \times 60) /$ Cardiac output $(\mathrm{ml} / \mathrm{min})$. Esophageal temperature was measured continuously at the level of the heart with a thermister probe and a telethermometer. $\$$ The temperature was maintained at $37 \pm 1^{\circ} \mathrm{C}$. Continuous data were recorded on a polygraph. I Input for the continuous reading was derived as follows:

\section{EKG}

Continuous standard lead electrocardiographic recordings were made.

\section{Aortic Flow}

A Zepeda nonferrous core type probe electromagnetic flowmeter was employed to measure aortic flow. ${ }^{19,24.29}$ The flowmeter traces were recorded directly on the polygraph.

\section{Exhaled Carbon Dioxide}

An infra-red carbon dioxide analyzer'|| was used to monitor the level of carbon dioxide in the expired air.

\section{Aortic Pressure}

Aortic pressure was measured by means of a Statham transducer attached to a catheter introduced through the femoral artery.

\footnotetext{
- Harvard Apparatus, Dual Phase Control Pump, Harvard Apparatus Co., Inc., Millis, Mass.

t Rotameter Model, Foregger G., Inc., New York, N.Y.

+ Astrup $\mathrm{pH}$ electrode, Severinghaus $\mathrm{P}_{\mathrm{CO}_{2}}$ electrode modified Clark $\mathrm{P}_{\mathrm{O}_{2} .}$ electrode connected to a Radiometer, Model 27, Copenhagen, Denmark.

$\S$ Telethermometer, Model 43TD, Yellow Springs Instrument Co., Yellow Springs, Ohio.

ॠBeckman Offner Type RB Dynograph, 6 Channel, Beckman Instruments, Inc., Schiller Park,

||Capnograph Type KK, Godart de Bilt, Holland.
} Ill. 


\section{Stroke Volume}

An integral of the aortic flow wave, triggered by the electrocardiogram QRS, was used to obtain a measure of stroke volume for each heart beat. ${ }^{24}$ This was recorded directly on a polygraph and from this measurement the cardiac output was determined.

The acupoint, Jen Chung (Go-26), was located by means of cutaneous impedance equipment, Acutest. ${ }^{\circ}$ Moxibustion was performed by means of electrocautery, Moxistimulator, $\uparrow$ at Jen Chung (Go-26). The probe, $3 \mathrm{~mm}$ in diameter, was maintained at $80 \pm 5^{\circ} \mathrm{C}$. This temperature appears well tolerated without permanent residual effect, although a blister is frequently observed.

The cauterizing probe was applied at Jen Chung (Go-26) or an adjacent neutral sitef for ten minutes (Figures 1 to 7 ). Measurements of the haemodynamic parameters were recorded every five minutes for the first 30 minutes and every 15 minutes for the ensuing 90 minutes. The control values for each animal were determined by two measurements taken 15 and 30 minutes prior to application of cautery at Jen Chung ( $\mathrm{Go}-26$ ) and expressed as 0 per cent.

Changes in cardiovascular parameters among the five groups: (1) anaesthesia only, (2) propranolol ( $0.5 \mathrm{mg} / \mathrm{kg}$-I.V.) only, (3) moxibustion at a neutral site, (4) moxibustion at Jen Chung (Go-26), and (5) propranolol prior to moxibustion at Jen Chung (Go-26), are included (Figures 1 to 7 ). Values for $\mathrm{pH}, \mathrm{Pa}_{\mathrm{CO}_{2}}, \mathrm{~Pa}_{\mathrm{O}_{2}}$ and base deficit were not significant at the 5 per cent level. The student " $t$ " test was used to compare values for ench parameter with its initial or control value.

\section{Results}

Measurements of the following cardiovascular parameters were made during a 120-minute period of observation: (1) cardiac output, (2) stroke volume, (3) heart rate, (4) mean arterial pressure, (5) pulse pressure, (6) central venous pressure, (7) total peripheral resistance, (8) $\mathrm{pH},(9) \mathrm{Pa}_{\mathrm{CO}_{2}}$, (10) $\mathrm{Pa}_{\mathrm{O}_{2}}$, and (11) base deficit. The first seven parameters are compared graphically (Figures 1 to 7 ). The values for $\mathrm{pH}, \mathrm{Pa}_{\mathrm{CO}_{2}}, \mathrm{~Pa}_{\mathrm{O}_{2}}$ and base deficit were not changed significantly since the $\mathrm{Pa}_{\mathrm{C}_{2} \mathrm{O}_{2}}$ was maintained at $40 \pm 2$ Torr. They are not included.

\section{Cardiac Output (Figure 1)}

Cardiac output was significantly increased at all time intervals following moxibustion with electric cautery at Jen Chung (Go-26). The cardiac output was significantly decreased following (1) the injection of propranolol alone, and (2) following the injection of propranolol and subsequent moxibustion at Jen Chung (Go-26). Values for the two control groups, (1) anaesthesia alone and (2) moxi-

'The Acutest, designed by one of the authors, D.C.L., measures resistance of the skin to a 6 volt, 100 microamp current. Jen Chung is located at midpoint of the philtrum.

†The Moxibustimulator, designed by one of the authors, D.C.L., is calibrated so that reading between 300 and 400 milliamps produce $80 \pm 5^{\circ} \mathrm{C}$ temperature in the probe.

1The neutral site or non-acupoints are areas adjacent to Jen Chung (Go-26) where cutaneous resistance is high allowing passage of a current of approximately 12 microamps while resistance is decreased permitting passage of a current of 60 microamps or more at acupoints. These determinations were made by cutaneous impedance equipment. 
bustion at a neutral site, were similar and in general, were not changed significantly."

\section{Stroke Volume (Figure 2)}

Stroke volume was significantly increased following moxibustion with electric cautery at Jen Chung (Go-26). Values at three time intervals were significantly decreased in the groups which received moxibustion at a neutral site. Values were not significantly changed in the following: (1) anaesthesia only, (2) propranolol only, (3) propranolol followed by moxibustion.

\section{Heart Rate (Figure 3)}

Heart rate was significantly increased at the beginning and the end of the 120minute period of observation in the group in which moxibustion was applied at Jen Chung (Go-26). Except for one time interval, all values in the groups which received: (1) propranolol alone, or (2) propranolol prior to moxibustion, were significant at the 5 per cent level. Two values at the 105- and 120-minute intervals were significantly increased in the group which was anaesthetized without further intervention while no values were significant in the group which received moxibusion at a neutral site.

\section{Mean Arterial Pressure (Figure 4)}

There was an early significant increase in mean arterial pressure in the group which received moxibustion by electrocautery at Jen Chung (Go-26). All values were significantly decreased in the groups which received propranolol alone and propranolol prior to moxibustion. One value at the 120 -minute interval was significantly decreased in the group in which moxibustion was performed at a neutral site. No values were significant in the control group with anaesthesia alone.

\section{Pulse Pressure (Figure 5)}

Early values for pulse pressure were significantly increased in the group which received moxibustion alone. Occasionally one or more significant values were observed for: (1) the group with anaesthesia alone, (2) the group with moxibustion at a neutral site, and (3) the group which received propranolol prior to moxibustion. Values for these three groups were close together. No significant value was observed for the group in which propranolol alone was administered.

\section{Central Venous Pressure (Figure 6)}

Central venous pressure was significantly elevated in some early values for the group which received propranolol alone. No significant changes were observed in the four remaining groups during the period of observation.

\section{Total Peripheral Resistance (Figure 7)}

Total peripheral resistance was significantly increased during the early part of the 120-minute period in the group which received propranolol alone and consistently decreased in the group in which moxibustion was performed at Jen Chung

\footnotetext{
- Data for the group in which moxibustion was performed at a neutral site resembled the group with anaesthesia only in all parameters.
} 


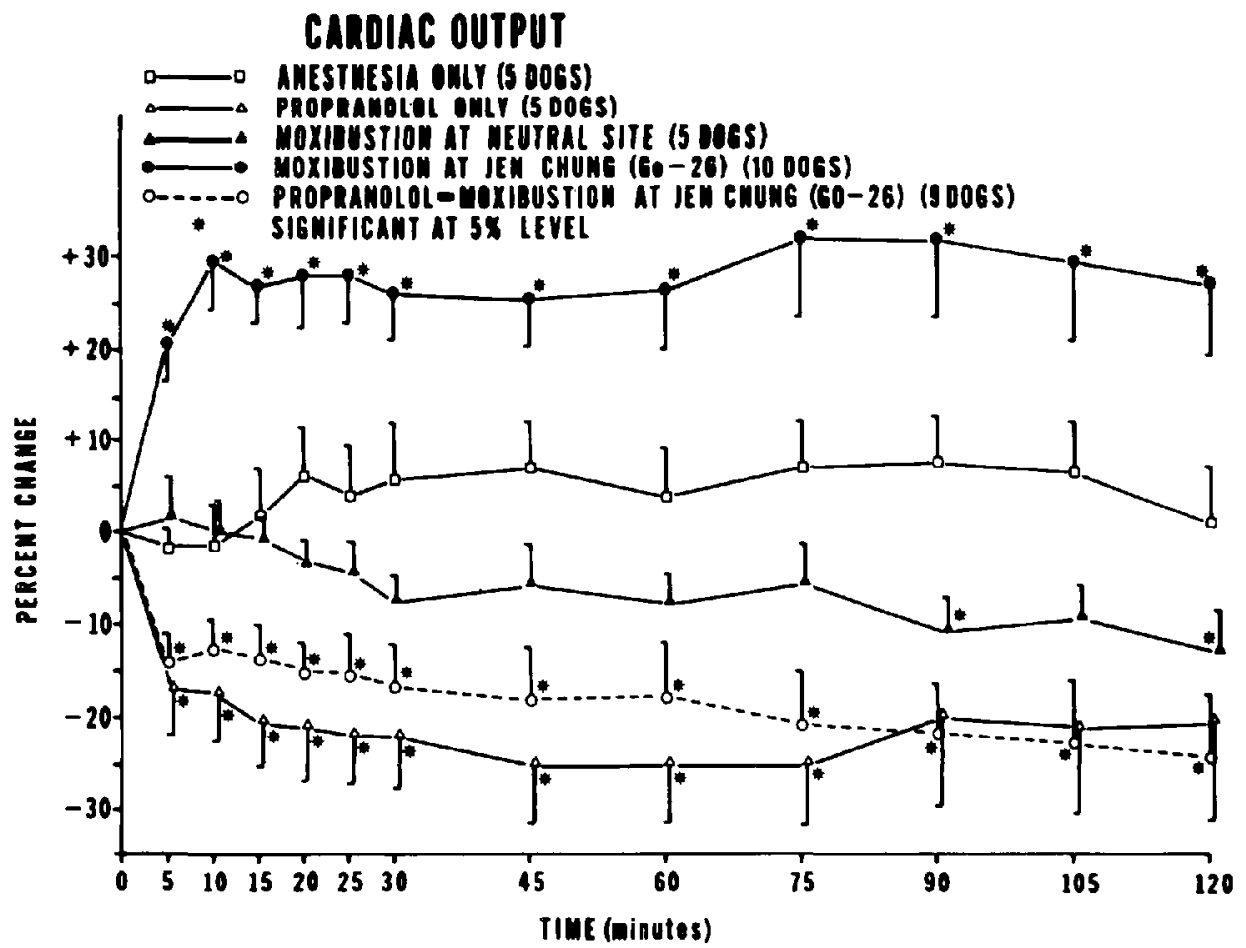

Figure 1. Effect of propranolol and/or moxibustion by electrocautery at Jen Chung (Go-26) on the cardiac output of dogs under MAC-I halothane anaesthesia.

\section{STROKE VOLUME}

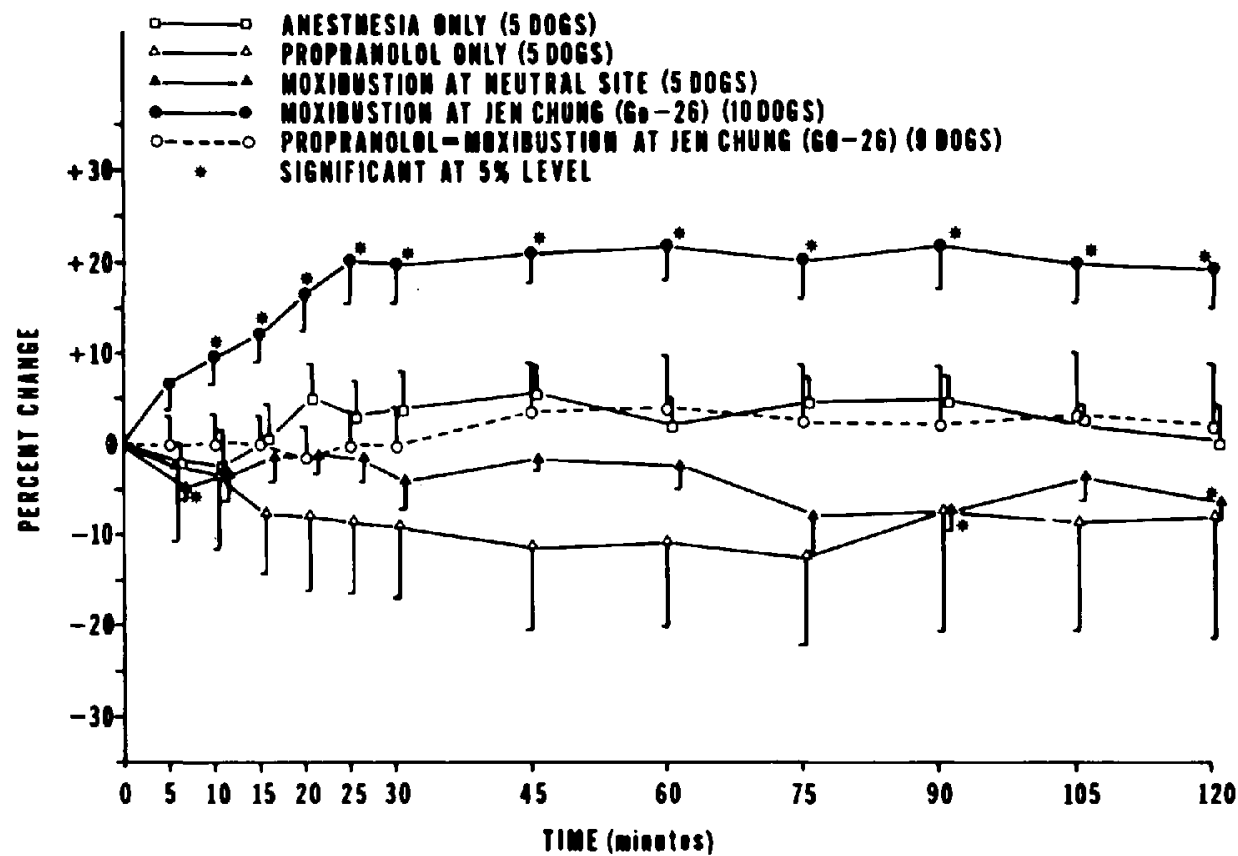

Figure 2. Effect of propranolol and/or moxibustion by electrocautery at Jen Chung (Go-26) on the stroke volume of dogs under MAC-1 halothane anaesthesia. 


\section{HEART RATE}

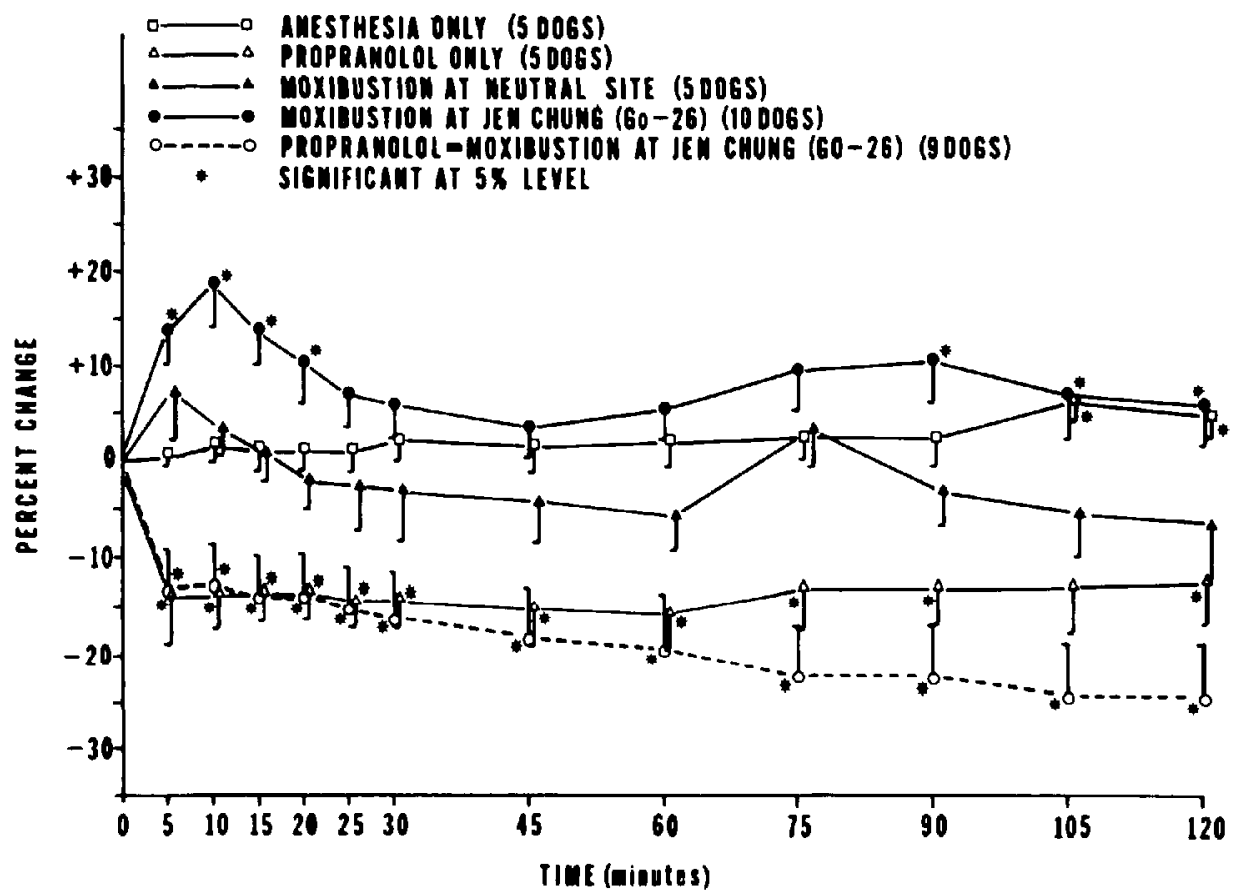

Ficune 3. Effect of propranolol and/or moxibustion by electrocautery at Jen Chung (Go-26) on the heart rate of dogs under MAC-1 halothane anaesthesia.

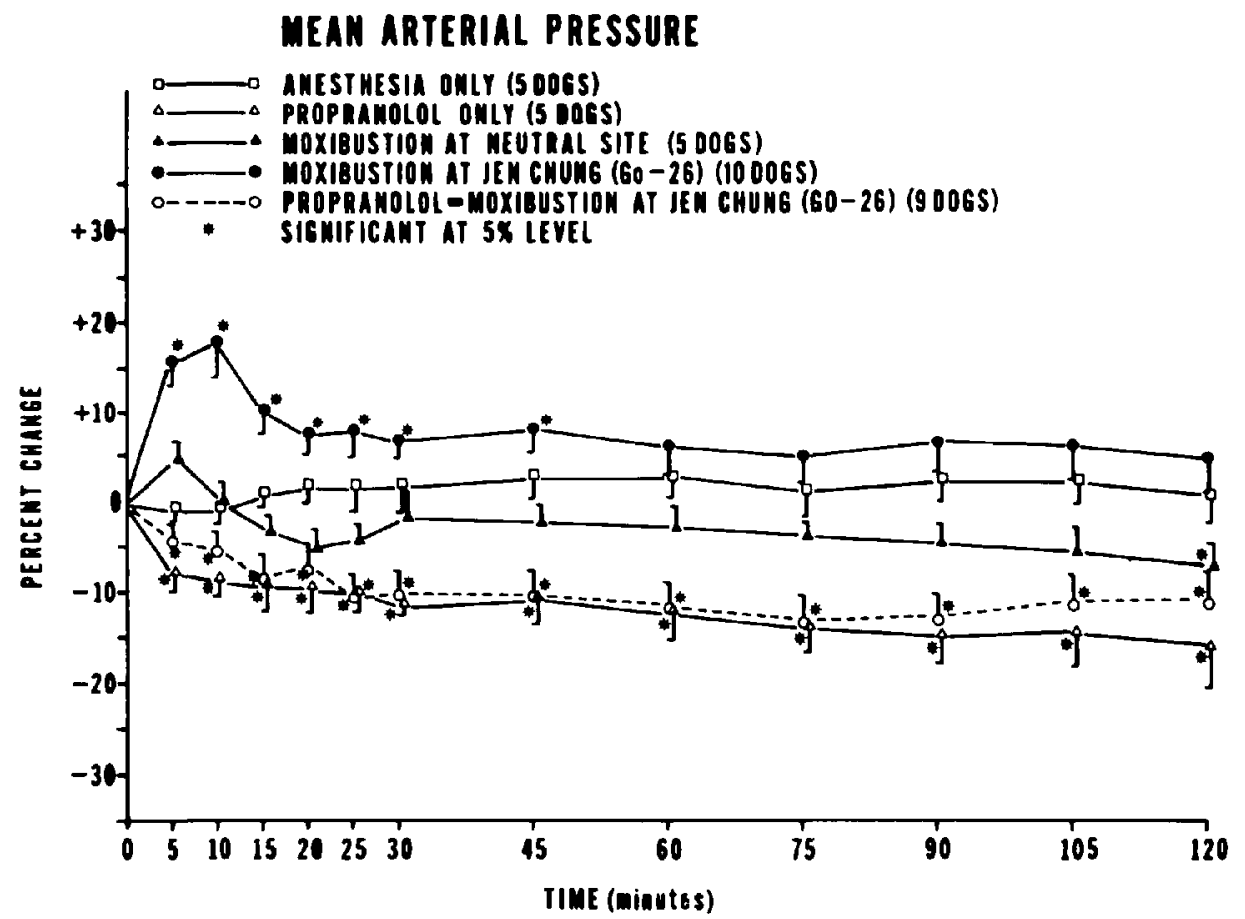

Figure 4. Effect of propranolol and/or moxibustion by electrocautery at Jen Chung (Go-26) on the mean arterial pressure of dogs under MAC-1 halothane anaesthesia. 


\section{PULSE PRESSURE}

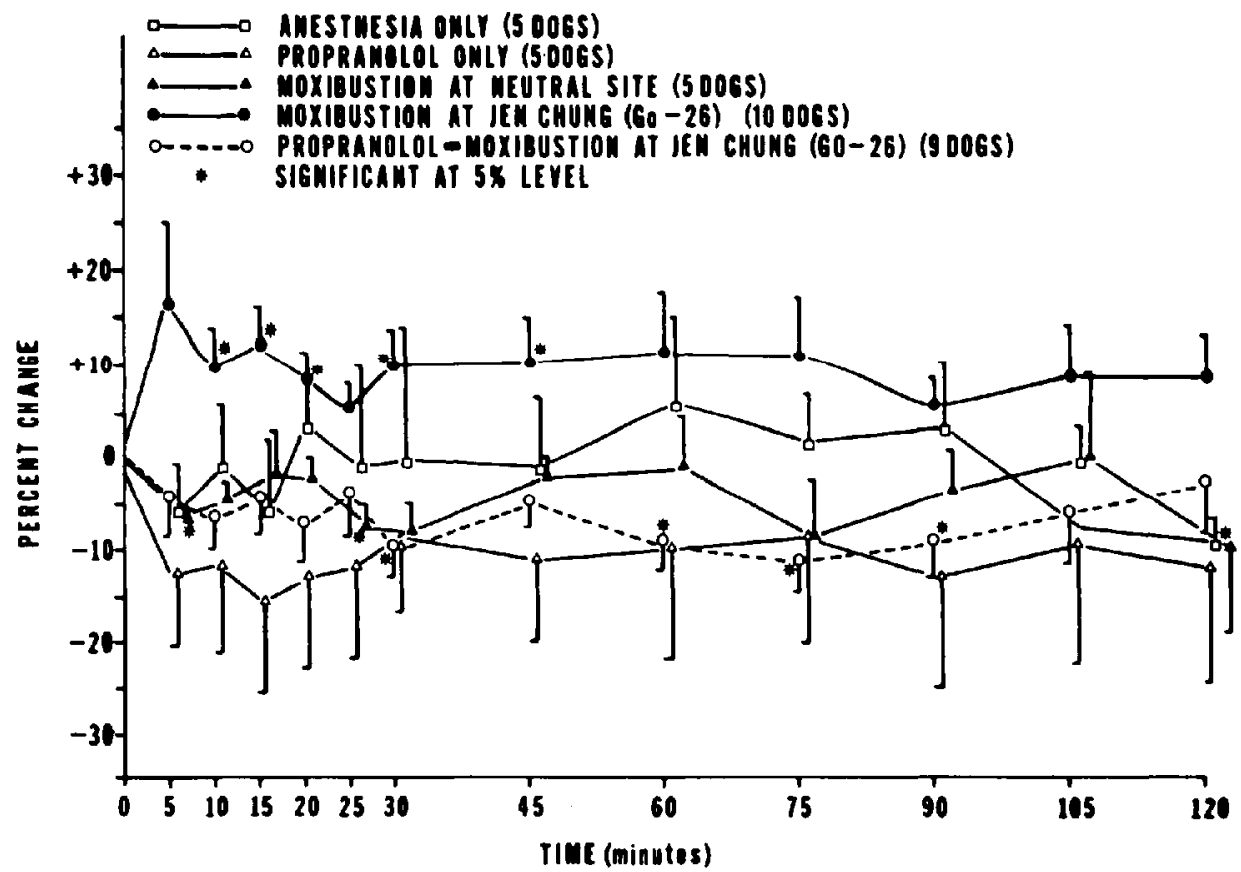

Figure 5. Effect of propranolol and/or moxibustion by electrocautery at Jen Chung (Go-26) on the pulse pressure of dogs under MAC-1 halothane anaesthesia.

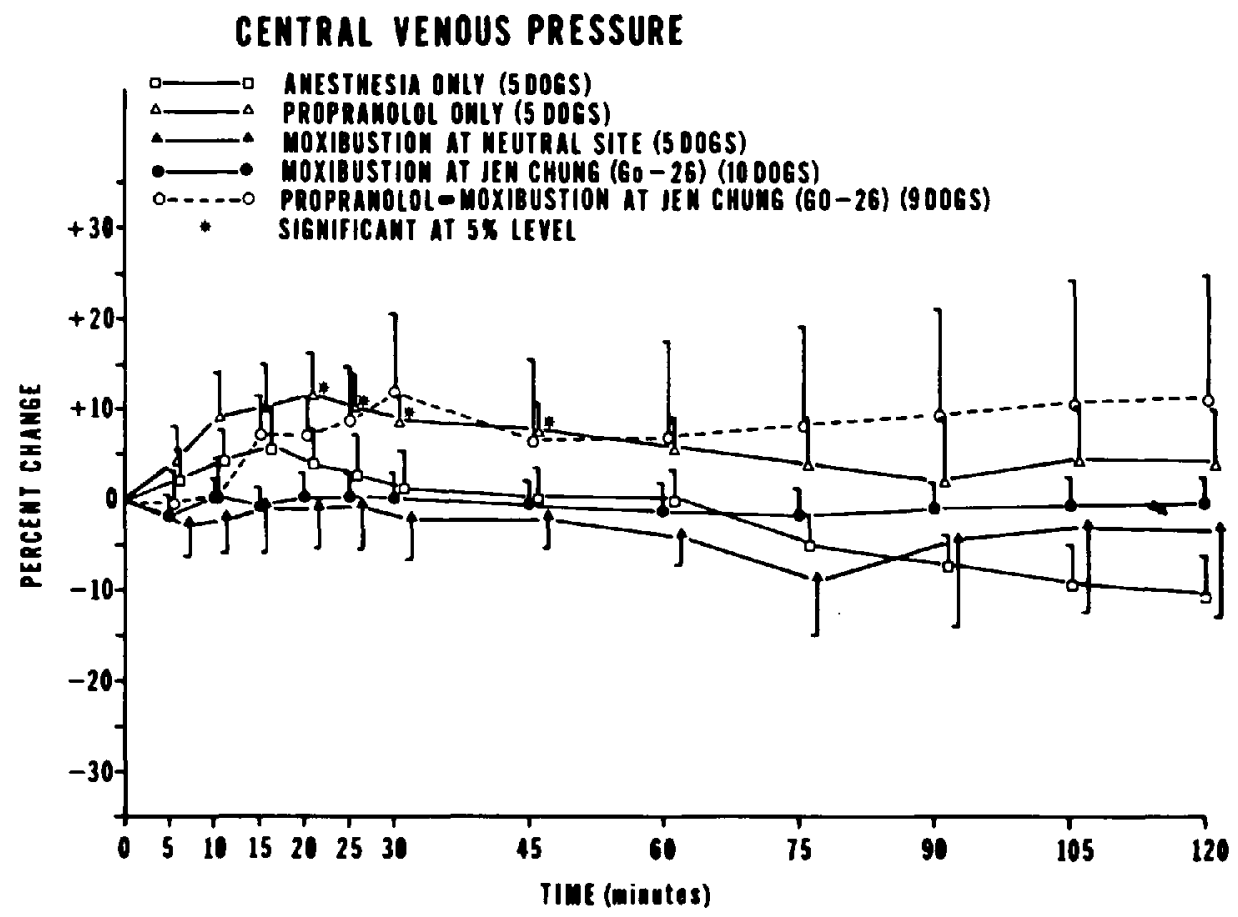

Figure 6. Effect of propranolol and/or moxibustion by electrocautery at Jen Chung (Go-26) on the central venous pressure of dogs under MAC-1 halothane anaesthesia. 


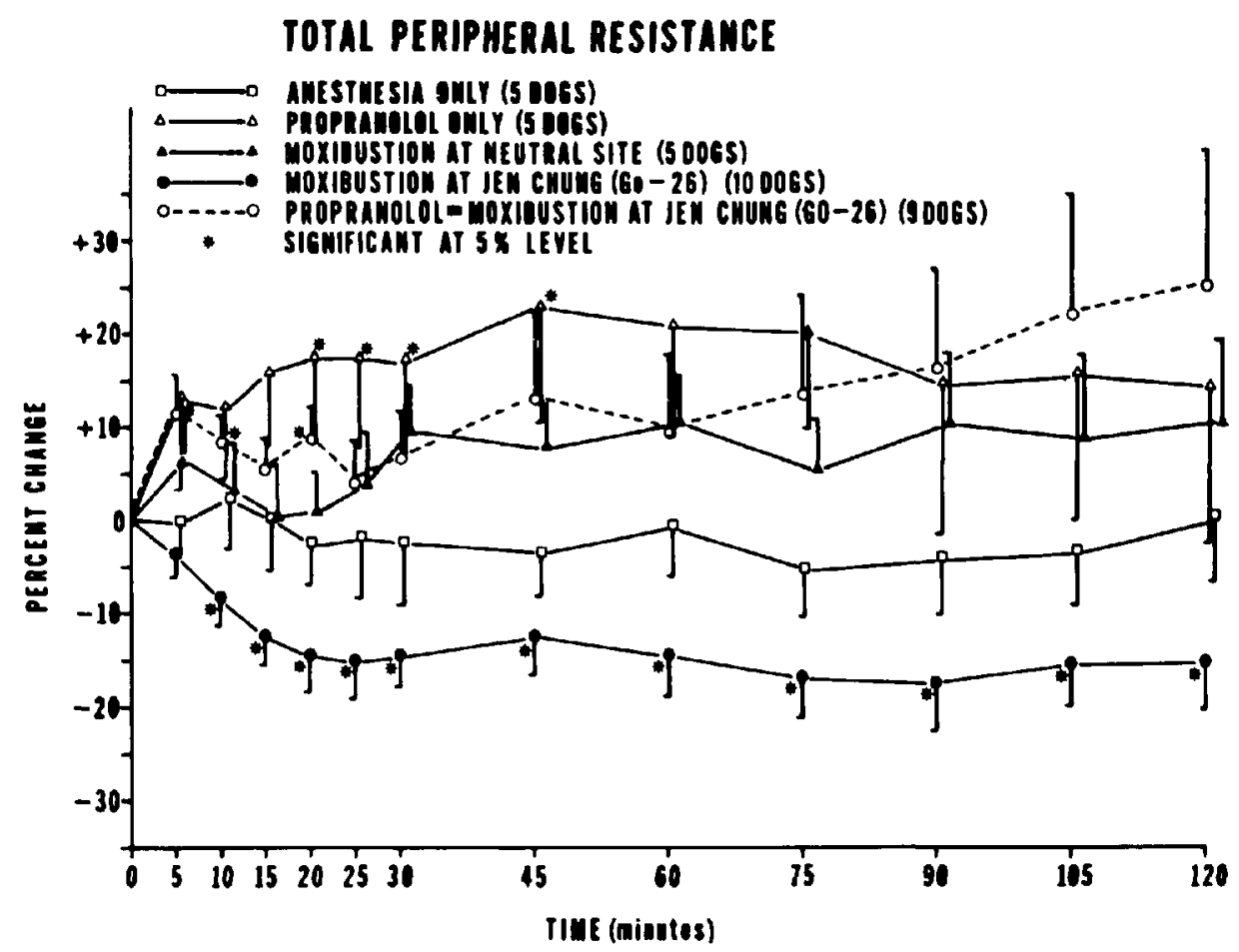

Figure 7. Effect of propranolol and/or moxibustion by electrocautery at Jen Chung ( $\mathrm{G} 0-26$ ) on the total peripheral resistance of dogs under MAC-1 halothane anaesthesia.

(Go-26). Two values were significantly increased for the group which received propranolol prior to moxibustion. Values for the two remaining groups, moxibustion at a neutral site and anaesthesia alone, were not significant.

\section{Discussion}

The results of this study indicate that the sympathomimetic effects of moxibustion by electrocautery at Jen Chung (Go-26) can be inhibited by the $\beta$-adrenergic blocking agent propranolol.

Cardiac output, which reflects the efficiency of the heart, was significantly increased following moxibustion by electrocautery at Jen Chung (Go-26) in dogs under halothane anaesthesia. Although this form of acupuncture is not used as commonly as needling, it produces a strong response. ${ }^{22.23}$ Intravenous injection of propranolol $(0.5 \mathrm{mg} / \mathrm{kg})$ alone or prior to moxibustion by electrocautery at Jen Chung (Go-26) resulted in a uniformly significant decrease in cardiac output in anaesthetized dogs. There is unanimity in published studies that propranolol: (1) produces a decrease in cardiac output by blocking $\beta$-adrenergic receptors, (2) does not affect the $\alpha$-receptors, and (3) is not vagolytic. ${ }^{301-44}$ Reports indicate that propranolol usually decreases the cardiac output significantly regardless of the 
species and whether an anaesthetic agent was or was not used. ${ }^{30-44}$ Cardiac output was observed to be significantly decreased by propranolol in unanaesthetized dogs that were exercised and not significantly changed in resting animals. ${ }^{36}$ The optimal dose range of propranolol needed to produce these effects is $0.2-1.0$ $\mathrm{mg} / \mathrm{kg} .{ }^{30-37,39-41,48} \mathrm{It}$ acts as a pure $\beta$-adrenergic blocker in doses under $2 \mathrm{mg} / \mathrm{kg} .{ }^{45}$ It has been shown that ether anaesthesia following the administration of propranolol $(0.5 \mathrm{mg} / \mathrm{kg})$ can be fatal in dogs. ${ }^{48}$

Stroke volume, heart rate, arterial pressure and pulse pressure which were increased markedly or significantly following moxibustion at Jen Chung (Go-26) in dogs under halothane anaesthesia were decreased when propranolol was administered prior to moxibustion. This decrease was observed following the injection of propranolol without subsequent moxibustion. These results are in accord with those observed by others following needling and moxibustion at Jen Chung (Go-26) and those observed following injection of propranolol alone. ${ }^{21,22,30-48}$

Total peripheral resistance was significantly decreased following moxibustion at Jen Chung (Go-26). This was increased following the administration of propranolol alone or prior to moxibustion at Jen Chung (Go-26). These results are in agreement with previous literature relative to the effects of propranolol alone..$^{30-35,40}$

The results of this study indicate that moxibustion by electrocautery at Jen Chung (Go-26) induces cardiovascular change by stimulating the sympathetic nervous system. Additional studies are needed to elucidate this mechanism.

\section{SUMMARY}

Acupuncture by electrocautery, moxibustion, at Jen Chung (Go-26) acupoint produces a sympathomimetic effect on the cardiovascular system of dogs under halothane anaesthesia (MAC I). This effect is manifest by significant increase in cardiac output, stroke volume, heart rate, mean arterial pressure and pulse pressure while total peripheral resistance is significantly decreased during a two-hour period of observation. Pretreatment with the beta blocker, propranolol, caused a significant decrease in cardiac output, heart rate, mean arterial pressure and pulse pressure while total peripheral resistance is significantly increased. Similar responses were observed when propranolol was administered without moxibustion at Jen Chung (Go-26).

\section{RÉSUMÉ}

L'acupuncture du point Jen Chung (Go-26) soit par aiguille avec rotation, ou de façon plus efficace par moxibustion par électro-cautère, modifie les paramètres cardio-vasculaires chez des chiens anesthésiés à l'halothane. On a administré du propranolol $(0,5 \mathrm{mg} / \mathrm{kg})$ à ces animaux avant la moxibustion afin de déterminer si les effets sympathicomimétiques manifestes de l'acupuncture pouvaient être inhibés. On a étudié chez ces chiens sous une anesthésie à l'halothane à MAC 1 le débit cardiaque, le volume d’éjection, la fréquence cardiaque, la pression 
artérielle moyenne, la pression artérielle différencielle, la pression veineuse centrale, les résistances périphériques totales, le $\mathrm{pH}$, la $\mathrm{Pa}_{\mathrm{CO}_{2}}$, la $\mathrm{P}_{\mathrm{O}_{2}}$ et le déficit-base.

Les chiens furent groupés comme suit:

groupe I: anesthésie seule

groupe II: propranolol seul

groupe III: acupuncture, moxibustion par électro-cautère à un point neutre groupe IV: acupuncture, moxibustion par electro-cautère au point Jen Chung (Go-26)

groupe V: propranolol puis acupuncture, moxibustion par électro-cautère du point Jen Chung (Go-26)

Le débit cardiaque, le volume d'éjection, la fréquence cardiaque, la PA moyenne et PA différencielle furent augmentés de façon significative tandis que les résistances vasculaires périphériques étaient significativement diminuées, pendant la période d'observation de 120 minutes suivant la moxibustion du point Jen Chung (Go-26) chez les chiens anesthésiés à l'halothane.

Après l'administration préalable de propranolol, le débit cardiaque, la fréquence cardiaque, la PA moyenne et la PA différencielle furent diminués de façon significative durant les deux heures qui suivirent la moxibustion. Cette étude montre que la moxibustion par électro-cautère du point Jen Chung (Go-26) entraîne des modifications cardiovasculaires par stimulation du système nerveux sympathique et que ces effets peuvent être inhibés chez les chiens anesthésiés à l'halothane par un blocage $\beta$ adrénergique préalable par le propranolol.

\section{ACKNOWLEDGMENTS}

The authors wish to thank Mr. Thomas Tenney, M.S.P.E., for technical assistance, Mr. Ramesh Parekh, M.S.I.E., for making the statistical comparisons, Mr. John Mull, Mr. Gerlad Lubinski and Mr. Ken Flora for aid with the illustrations and Mrs. Ann Hansen for aid in preparing the manuscript. The halothane (Fluothane ${ }^{\circledR}$ ) and propranolol (Inderal ${ }^{\circledR}$ ) were generously supplied by Ayerst Laboratories.

\section{REFERENCES}

1. Verth, I. The yellow emperor's classic of internal medicine. Berkeley, Calif.: University of California Press (1949).

2. VEITH, I. Acupuncture in traditional Chinese medicine - an historical review. Calif. Med. 118: 70 (1973).

3. Bonica, J.J. Therapeutic acupuncture in the People's Republic of China. Implications for American medicine. J.A.M.A. 228-: 1544 (1974).

4. Dimond, E.G. Acupuncture anesthesia. Western medicine and Chinese traditional medicine. J.A.M.A. 218: 1558 (1971).

5. Man, P.L. \& Chen, C.H. Acupuncture "Anesthesia" - A new theory and clinical study. Curr. Therap. Res. 14: 390 (1972).

6. Mann, F., Bowsher, D., Mumfond, J., Lipton, S., \& Miles, J. Treatment of intractable pain by acupuncture. Lancet $l: 57$ (1973).

7. Peng, A.T.C., Omuna, Y,, Cheng, H.C., \& Blancato, L.S. Acupuncture for relief of chronic pain and surgical analgesia. Amer. Surg. 125: 50 (1973).

8. PERlow, B.W. Acupuncture: its theory and use in general practice. Proc. Roy. Soc. Med. 66: $426(1973)$. 
9. Wallis, L., Shnimer, S.M., Palahniuk, R.J., \& Spivey, H.T. An evaluation of acupuncture analgesia in obstetrics. Anesthesiology $41: 596$ (1974).

10. BEAU, G. Chinese Medicine, N.Y., N.Y.: Avon Publishers (1972).

11. Choz, Y.T. \& Lee, S.H. Acupuncture and Moxibustion Meridians and Points. Seoul, Korea: Ko Moon Sa (1973).

12. Duke, M. Acupuncture. N.Y., N.Y.: Pyramid Communications, Inc. (1972).

13. Manaka, Y. \& Unquhart, I.A. The Layman's Guide to Acupuncture, N.Y., N.Y.: Weatherhill, pp. 104-105, 115-116 (1972).

14. Mann, F. Acupuncture, the ancient Chinese art of healing and how it works scientifically. N.Y.: Vintage Books (1973).

15. Matsumoto, T. Acupuncture for physicians. Springfield, Ill. (1973).

16. Wallnöfer, H. \& von Rottauscher, A. Chinese folk medicine. Bergenfield, N.J.: New American Library, Inc. pp. 135 (1971).

17. Worsley, J.R. Is Acupuncture for You? N.Y.: Harper \& Row Publishers, pp. 10 (1973)

18. LEE, D.C. Comparison of the effects of acupuncture with needlitng, twirling and electrical stimulation or digital pressure on the cardiovascular system of anesthetized dogs. Acupuncture Res. 4 (Dec. 1974-Jan. 1975).

19. LEE, D.C., LEe, M.O., \& ClifFord, D.H. Cardiovascular effects of acupuncture in anaesthetized dogs. Am. J. Chinese Med. 2: 271 (1974).

20. LeE, M.O., LEE, D.C., KIM. S., \& Clifford, D.H. Cardiovascular effects of acupuncture at Tsu San Li (St-36) in dogs. J. Surg. Res. 18:51 (1975).

21. Lee, D.C., LeE, M.O., \& Clifford, D.H. Cardiovascular effects of moxibustion at Jen Chung (Go-26) during halothane anesthesia in dogs. Submitted to Am. J. Chinese Med. $(1975)$

22. LeE, D.C., Yoon, D.S., Lee, M.O., \& ClifFord, D.H. Comparison of the effects of two types of acupuncture (needling and moxibustion) on the cardiovascular dynamics of anesthetized dogs. Submitted to J. Applied Physiol. (Jan. 1976).

23. LEE, D.C. \& JoHNSON, D.L. Effect of D-tubocurarine and anaesthesia upon cardiac output in normal and histamine-depleted dogs. Canad. Anaesth. Soc. J. 18: 157 (1971).

24. Scher, A.M., Zepeda, J., \& Bhown, O.F. Squarewave electromagnetic flowmeter employing commercially available recorder. J. Appl. Physiol. 18: 1265 (1963).

25. Brady, A.F., Stupfel, M. \& Severinghaus, J.W. Effect of temperature on $P_{C o}$, and $P_{O_{1}}$ of blood in vitro. J. Appl. Physiol. 9: 201 (1956).

26. Carson, S.A.A., Chorley, G.E., Hamilton, F.N., Lee, D.C., \& Morris, L.E. Variation in cardiac output with acid-base changes in the anesthetized dog. J. Appl. Physiol. 20: 948 (1965).

27. Rosenthal, T.B. The effect of temperature on the $\mathrm{pH}$ of blood and plasma in vitro. J. Biol. Chem, 173: 25 (1948).

28. Green, H.D., Lewis, R.N., Nickerson, N.D., \& Heller, A.L. Blood flow, peripheral resistance and vascular tonus, with observations on the relationship between blood flow and cutaneous temperature. Am. J. Physiol. 141: 518 (1944).

29. Hamilton, F.N., Minzel, J.C., \& Schlobohm, R.M. Measurement of cardiac output by two methods in dogs. J. Appl. Physiol. 22: 362 (1967).

30. AdAM, K.R. \& BoYLes S.M. Haemodynamic and coronary vascular responseses after $\beta$-adrenoceptor blockade in the anaesthetized dogs: a comparison of tolamolol with practolol and propranolol. Eur. J. Pharmacol. 26: 96 (1974).

31. Andres, J.F., White, F.C., \& Bloon, C.M. Coronary and systemic hemodynamic effects of propranolol and practolol compared in the resting, conscious dogs. Res. Commun. Chem. Pathol. \& Pharmacol. 7: 481 (1974).

32. Bergamashi, M., Shanks, R.G., Cararoggi, A.M., \& Mandelli, V. A comparison of the cardiovascular actions of four adrenergic $\beta$-receptor blocking agents in resting conscious dogs. Am. Heart J. 82:338 (1971).

33. Branch, R.A., Shand, D.G., \& NiEs, A.S. Hemodynamic drug interactions: The reduction of oxyphenbutazone clearance by dl-propranolol in the dog. J. Pharmacol. \& Exp. Ther. 187: 133 (1973).

34. Branch, R.A., Shand, D.G., Wilkinson, G.R., \& Nies, A.S. The reduction of lidocaine clearance by dl-propranolol - An example of hemodynamic drug interaction. J. Pharmacol. \& Exp. Ther. 184: 515 (1973).

35. Craythonne, N.W.B. \& Huffington, P.E. Effects of propranolol on the cardiovascular response to cyclopropane and halothane. Anesthesiology 27:58 (1966). 
36. Ehrlich, W., Schrijen, F.V., Krausman, D.T., Caldinin, P., \& Brady, J.V. The effect of beta-blockade on coronary and systemic circulation in dogs at rest and during adaptation to exercise. Arch. Int. Pharmacodyn. Ther. 204: 213 (1973).

37. Gander, M., Veragut, U., Kohler, R., \& Luthy, E. Cardiac haemodynamics under $\beta$-receptor blockade in dogs. Symposium on Propranolol, Cardiologia Supplementum II 49: 17 (1966).

38. Jorfeldt, L., Lofstrom, B., Moller, J., \& Rosen, A. Cardiovascular effects of betareceptor blocking drugs during halothane anaesthesia in man. Acta Anaesth. Scandinav. 14: 35 (1970).

39. MACHIDA, K. The changes of left and right ventricular volumes induced by propranolol and subsequent carotid occlusion. Jap. Heart J. 13: 445 (1972).

40. Merin, R.G. \& Tonnesen, A.S. The effect of beta-adrenergic blockade on myocardial haemodynamics and metabolism during light halothane anaesthesia. Can. Anaes. Soc. J. 16: 336 ( 1969 ).

41. Nakano, J. \& Kusakani, T. Effects of beta adrenergic blockade on the cardiovascular dynamics. Am. J. Physiol. 210: 833 (1966).

42. Shanks, R.G. The pharmacology of beta sympathetic blockade. Am. J. Cardiology 18: 308 (1966).

43. Sowton, E. \& Hamer, J. Hemodynamic changes after beta adrenergic blockade. Am. J. Cardiol. 18: 317 (1966).

44. Stephen, S.A. Unwanted effects of propranolol. Am. J. Cardiology 18:463 (1966).

45. Harry, J.D., Kappagoda, C.T., Linden, R.J., \& Snow, H.M. Action of propranolol on the dog heart. Cardiovasc. Res. 7: 729 (1973).

46. McClish, A., Andrew, D., Moisan, A., \& Monin, Y. Intravenous propranolol for cardiac disturbances in relation to halothane anesthesia for cardiovascular surgery. Canadian Medical Assoc. J. 99: 388 (1968).

47. Warnen, W.A. Beta-adrenergic blocking agents and anaesthesia: A review. Can. Anaes. Soc. J. 15: 42 ( 1968).

48. Rouse, $W$. The effects of propranolol on the response to ether anesthesia in dogs. Anaesthesia 24: 157 (1969). 